\title{
NEUTRON ACTIVATION ANALYSIS TO PROBE THE AIR POLLUTION USING PLANT BIOMONITORING IN EGYPT
}

\author{
Yasmin Sarhan', Wael Badawy ${ }^{2,3}$, Marina Frontasyeva ${ }^{3}$, \\ Wafaa Arafa ${ }^{4}$, Abd El Azeem Hussein', Hussein El-Samman ${ }^{1 *}$ \\ ${ }^{1}$ Department of Physics, Faculty of Science, Menoufia University, Egypt \\ ${ }^{2}$ Egyptian Atomic Energy Authority (EAEA), Nuclear Research Center, Radiation Protection \& Civil Defense Dept. \\ Abu Zaabal, Egypt \\ 3Frank Neutron Physics Laboratory, Joint Institute for Nuclear Research, Dubna, Russian Federation \\ 4Department of Physics, Faculty of Women, Ain Shams University
}

\begin{abstract}
A comprehensive characterization of the biomonitoring of air pollution assessment using Eucalyptus Globulus and Ficus Nitida plants in Cairo and Minoufia cities in Egypt is given. The concentrations (ppm) of thirtytwo elements were determined in 30 leaf samples by means of the epithermal neutron activation analytical technique. The collected samples were irradiated by epithermal neutrons at REGATA -pulsed reactor IBR-2 in Dubna, Russian Federation. The obtained concentrations of; $\mathrm{Na}, \mathrm{Mg}, \mathrm{Al}, \mathrm{Cl}, \mathrm{K}, \mathrm{Ca}, \mathrm{Sc}, \mathrm{Ti}, \mathrm{V}, \mathrm{Cr}, \mathrm{Mn}, \mathrm{Fe}, \mathrm{Co}, \mathrm{Ni}, \mathrm{Zn}, \mathrm{As}, \mathrm{Se}, \mathrm{Br}, \mathrm{Rb}, \mathrm{Sr}$, $\mathrm{Sb}, \mathrm{I}, \mathrm{Cs}, \mathrm{Ba}, \mathrm{La}, \mathrm{Sm}, \mathrm{Tb}, \mathrm{Hf}$, Ta, $\mathrm{Au}, \mathrm{Th}$, and $\mathrm{U}$ were compared to the reference plant. The analysis of the obtained concentrations revealed that the concentrations at some sites in Menoufia Governorate were significantly higher than those in Cairo, in spite of the intense population, heavy traffic, and vehicle waste disposed in Cairo. The remarkable increase of metals in Menoufia Governorate has occurred most probably due to the uncontrolled disposal of industrial and domestic waste. In addition, the study shows the Ficus Nitida plant responsiveness to metals is higher than Eucalyptus Globulus.
\end{abstract}

Keywords: Air pollution, biomonitoring, elemental concentration, neutron activation analysis, tree leaves

\section{INTRODUCTION}

Atmospheric pollution has been a problem of great concern due to the high risk of even small concentrations of pollutants. Atmospheric pollution is a process that introduces diverse pollutants into the atmosphere; it causes harm to humans, other living organisms, and the natural environment[1]-[3]. By increasing the rate of urbanization and industrial zones, the level of atmospheric pollution is getting worse. So, it is necessary to study (monitor) the level of atmospheric pollution to take the necessary precautions against it. There are traditional methods of atmospheric monitoring, namely remote sensing, rainwater analysis, sampling of air, measurements of gas concentrations and accelerating air through multiple narrowing nozzles. During the recent decades, tree leaves have been used as biomonitors [4][5]. Plants represented a significant capability to retain transported pollutants by air and deposited on leaves. Here of, mosses and lichens, because of their rootless nature, showed the best capacity to accumulate metals from air. In hot and arid regions, mosses and lichens are not growing, therefore, the vascular plant showed to be good indicators of airborne pollutants. Various studies using leaves and other parts of trees revealed the capabilities of these technique as biomonitoring technique [6][7], [8]. In the present study the quality of air was assessed using two evergreen vascular plants' leaves Eucalyptus Globulus and Ficus Nitida as both of these two species are wide disseminated in this region.

Such a technique is used to analyze living organisms, and it is a quantitative, qualitative and multi-elemental analytical technique. Neutron Activation Analysis technique (NAA) is highly sensitive, selective, and nondestructive in nature; it allows one to identify many elements simultaneously in the same sample and does not require complex chemical separation methods. This technique is widely used in studies in geology, biology, medicine, ecology, and material science [9].

\section{MATERIALS AND METHODS}

\subsection{Study area}

The samples used in this study were collected from two main districts in Egypt Greater Cairo and Menoufia Governorates. The samples were used to study the level of atmospheric pollution in the surrounding environment. Thirty samples were

\footnotetext{
*hsamman@aucegypt.edu
} 
collected from different districts in Greater Cairo and Menoufia, in particular from polluted areas roadside, highways, industrial zones, traffic areas, brick kilns, and train and bus stations, etc. Twenty leaf samples were collected from Greater Cairo and ten samples were collected from Menoufia Governorate. The samples were collected during March and April 2018. Evergreen tree leaves were used as bio-monitors of atmospheric pollution. In Table 1, the sampling sites of areas under investigation in Cairo and Menoufia Governorates are shown.

Table 1. Sampling sites

\begin{tabular}{|c|c|c|}
\hline ID & PLACE & PLANT SPECIES \\
\hline 1 & $\begin{array}{l}\text { Shubra El Kheima (Crystal } \\
\text { Asfour) }\end{array}$ & Eucalyptus Globulus \\
\hline 2 & Ramsis & Ficus Nitida \\
\hline 3 & Tahrir & Ficus Nitida \\
\hline 4 & El-Sayyeda Zainab & Ficus Nitida \\
\hline 5 & Al-Sahel & Ficus Nitida \\
\hline 6 & El-Sharrabeya & Eucalyptus Globulus \\
\hline 7 & $\begin{array}{l}\text { Shubra El Kheima (Power } \\
\text { Station) }\end{array}$ & Ficus Nitida \\
\hline 8 & El Ma'aadi & Eucalyptus Globulus \\
\hline 9 & Musturod & Eucalyptus Globulus \\
\hline 10 & Basus & Eucalyptus Globulus \\
\hline 11 & Atati - Al Haram & Ficus Nitida \\
\hline 12 & El- Haram (Nazlet El Batran) & Eucalyptus Globulus \\
\hline 13 & Kafr Nassar- Giza & Ficus Nitida \\
\hline 14 & $\begin{array}{l}\text { Nasr City: (Al Azhar } \\
\text { University) }\end{array}$ & Eucalyptus Globulus \\
\hline 15 & $\begin{array}{l}\text { Al- Amireyya (Industrial } \\
\text { Zone) }\end{array}$ & Ficus Nitida \\
\hline 16 & $\begin{array}{l}\text { El-Qawmeya El Arabeya - } \\
\text { Imbaba }\end{array}$ & Ficus Nitida \\
\hline 17 & El- Basateen & Eucalyptus Globulus \\
\hline 18 & El Darb El-Ahmar & Eucalyptus Globulus \\
\hline 19 & Al-Azhar Park & Ficus Nitida \\
\hline 20 & El-Qanater El Khairya & Eucalyptus Globulus \\
\hline 21 & Menouf & Eucalyptus Globulus \\
\hline 22 & Sirs El Layyan & Eucalyptus Globulus \\
\hline 23 & Sadat City & Ficus Nitida \\
\hline 24 & Ashmoun & Ficus Nitida \\
\hline 25 & Berket El Saab' & Eucalyptus Globulus \\
\hline 26 & Shebin El Kom & Eucalyptus Globulus \\
\hline 27 & Al Shuhadaa & Ficus Nitida \\
\hline 28 & Al Bagour & Ficus Nitida \\
\hline 29 & Hit - Menoufia & Ficus Nitida \\
\hline 30 & Hit - Menoufia & Eucalyptus Globulus \\
\hline
\end{tabular}

\subsection{Sample collection and preparation}

Leaves from 2 species of trees; Eucalyptus Globulus and Ficus Nitida that are common in Egypt were used in this study. These species were chosen because they have a widespread distribution in Egypt. Ficus Nitida has the ability to take up particulates more than other tree species at the same sampling site. They are both drought tolerant and sensitive to damage of their physiology by heavy metal pollution and they are suitable for biomonitoring in dry countries [7]. Leaves were collected randomly at all sides from trees at a height between 1.7 and 2 meters above the ground. The collecting process was conducted using latex gloves made of rubber and the samples were stored in suitable bags to prevent the tree leaves from getting rotten until being taken and processed in the laboratory. The tree leaves were chosen to be approximately at the same phenological state to avoid inaccuracies. The sampling process was conducted according to the recommendations of several authors and guide lines[4][10]. The tree leaves were taken to the laboratory, washed 3 times with distilled water to eliminate the effect of dust on the leaf surface and dried at room temperature then dried in oven at a constant temperature of 40 degrees for 7 days. The dried tree leaves were pulverized in agate grinder until they were turned into powder and then packed in polyethylene zipped bags until being prepared for irradiation process. Two samples of 0.3 grams from each sampling site were prepared. Samples were pressed in mechanical piston to obtain pellets of $1.5 \mathrm{~cm}$ diameter and $0.3 \mathrm{~cm}$ height. These pellets were packed in Aluminum cap for long irradiation and in polyethylene bag for short irradiation.

\subsection{Irradiation process}

The samples were irradiated by epithermal neutrons in The IBR-2 reactor of FLNP JINR which is equipped with two irradiation channels of pneumatic transport system; the experimental setup is called REGATA. One of the 2 irradiation channels is cadmium screened for irradiation with epithermal neutrons. For short-lived isotope measurements, the sample was wrapped in a polyethylene bag and irradiated for $3 \mathrm{~min}$ in channel 2, then measured for 15 minutes (after 3 to 5 min of decay) using gamma ray spectrometer with hyper pure germanium. In the case of long-lived isotopes, the samples in aluminum caps were irradiated for approximately 3 days in the Cd screened channel 1 with a neutron flux of $1.8 \times 10^{11} \mathrm{n} / \mathrm{cm}^{2} \cdot \mathrm{s}$. The samples were repacked and measured first after 3 days of decay for 30 min and then after 20 days of decay for $1.5 \mathrm{~h}$ [9], [11], [12]. Genie20oo software was used to store, display, and analyze the gamma spectra. The concentrations of the elements in the samples were determined using a software developed at FLNP [13]. The analytical errors in the concentrations of the relevant elements ranged from 3 to $15 \%$.

The SRMs used for the quality control for NAA of plant samples are NIST SRM 1547-PeachLeaves, NIST SRM1575a-PineNeedles, NIST SRM1633b-CoalFlyAsh, NIST SRM1632c-Coal(Bituminous), NIST SRM 2709 San Joaquin Soil, IRMM SRM 667 - Estuarine Sediment. SRM material varied between $1 \%$ and $10 \%$ with the exception of $\mathrm{Rb}, \mathrm{Ti}, \mathrm{Ni}, \mathrm{Mo}, \mathrm{Au}, \mathrm{Hf}, \mathrm{W}$, and I. for which the differences were $17 \%$ for $\mathrm{Rb}, 20 \%$ for $\mathrm{Ti}$ and $\mathrm{Ni}, 30 \%$ for $\mathrm{Mo}$ and $\mathrm{Au}, 33 \%$ for $\mathrm{Hf}$ and $\mathrm{W}$, and $39 \%$ for I [14].

\section{RESULTS AND DISCUSSION}

The obtained concentration in $\mathrm{mg} / \mathrm{kg}$ of 32 elements were determined; namely $\mathrm{Na}, \mathrm{Mg}, \mathrm{Al}, \mathrm{Cl}, \mathrm{K}$, $\mathrm{Ca}, \mathrm{Sc}, \mathrm{Ti}, \mathrm{V}, \mathrm{Cr}, \mathrm{Mn}, \mathrm{Fe}, \mathrm{Co}, \mathrm{Ni}, \mathrm{Zn}$, As, Se, Br, Rb, Sr, $\mathrm{Sb}, \mathrm{I}, \mathrm{Cs}, \mathrm{Ba}, \mathrm{La}, \mathrm{Sm}, \mathrm{Tb}, \mathrm{Hf}, \mathrm{Ta}, \mathrm{Au}, \mathrm{Th}$, and $\mathrm{U}$.

These elements were divided into 3 subgroups: toxic elements, major elements and trace elements. 


\subsection{Toxic elements}

According to [15], Sb, Co, V, Cr, Ni, As, Se, Ba, Zn and $\mathrm{Ti}$ are classified as toxic elements.

The following 3-D figure shows the concentrations in $\mathrm{mg} / \mathrm{kg}$, toxic elements and sampling sites.

The measurements show that the concentrations of arsenic (As) and Antimony ( $\mathrm{Sb}$ ) varied between 0.36 and $2.5 \mathrm{mg} / \mathrm{kg}$ and 0.02 and $0.62 \mathrm{mg} / \mathrm{kg}$ respectively. These elements are related to human toxicity and ecotoxicity. These elements are associated with the sources of traffic and roads and coal burning [16][17] and the highest values were measured in Cairo, near the roads of heavy traffic zones. It is noticeable that Shubra El Kheima power station area has the highest concentration because of coal fuel burning due to it being one of the biggest traffic areas in Cairo. The published toxic level is 5:20 for As and 150 for $\mathrm{Sb}$.

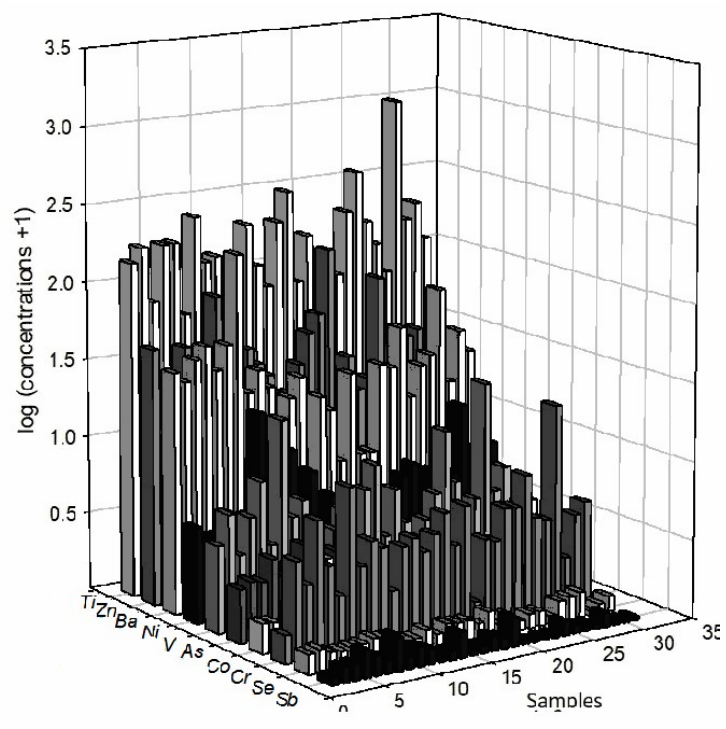

Figure 1. Log (concentrations +1 ) of Toxic elements is sampling sites

Barium(Ba) varied between 3 and $173 \mathrm{mg} / \mathrm{kg}$ and found mostly in Cairo because of heavy traffic roads [16]. The highest concentration value was detected near Shubra El Kheima power station location. This might be because of fossil fuel burning [17] (coal Fuel). However, the highest $\mathrm{Ba}$ concentration value was detected at Al Shuhadaa area in Menoufia governorate near a diesel fuel station used by the trains. The toxic level of $\mathrm{Ba}$ is $500 \mathrm{mg} / \mathrm{kg}$.

The main sources of Selenium are the burning of fossil fuels, steel processing and sewage sludge to land where the concentration varied between 0.07 and $0.45 \mathrm{mg} / \mathrm{kg}$. The toxic level is $5: 30 \mathrm{mg} / \mathrm{kg}$.

The highest concentration of cobalt was found at Al-Shuhadaa in Menoufia Governorate and near the electric power station in Shubra El Kheima in Cairo. The concentration of Cobalt in Menoufia is higher than the concentrations in Cairo. The concentration of Co varied between 0.14 and $3.4 \mathrm{mg} / \mathrm{kg}$ while the toxic level is $15: 20 \mathrm{mg} / \mathrm{kg}$.

The concentration of Chromium varied between 0.4 and $19 \mathrm{mg} / \mathrm{kg}$. The highest value was detected in $\mathrm{Al}$ shuhadaa train station area in Menoufia then in Shubra El Kheima power plant because of the burning of the fossil fuel [18] used in the power station in Shubra El Kheima in Cairo [18]. The toxic level is $5: 30 \mathrm{mg} / \mathrm{kg}$.

The highest concentration of Nickel was in Shubra El Kheima power station, then in Al Shuhadaa. The main source of $\mathrm{Ni}$ is the burning of fossil fuels and wind-blown dust. The concentration of $\mathrm{Ni}$ varied between 0.14 and $17.7 \mathrm{mg} / \mathrm{kg}$ while the toxic level is $10: 100 \mathrm{mg} / \mathrm{kg}$.

The concentration of $\mathrm{Ti}$ varied between 46 and $991 \mathrm{mg} / \mathrm{kg}$ and the highest value was found in $\mathrm{Al}$ Shuhadaa, Menoufia due to the waste of batteries, motors and wind-blown dust [19] because of the nonpaved ground and dust as a result of trains. The toxic level is 50: $200 \mathrm{mg} / \mathrm{kg}$. The data show that $\mathrm{Ti}$ represents a considerable source of pollution in all investigated areas.

The concentration of Vanadium (V) varied between 1.22 and $18.8 \mathrm{mg} / \mathrm{kg}$ and the highest value was found at Al Shuhadaa in Menoufia and Shubra El Kheima power station in Cairo, then in Sadat city industrial zone in Menoufia Governorate. The toxic level is $5: 10 \mathrm{mg} / \mathrm{kg}$. The main sources of Vanadium are fossil fuel burning, friction in gears, burning oils used in the industries [17],municipal sewage sludge, and certain fertilizers [20].

The main sources of $\mathrm{Zn}$ are heavy traffic and rubber derived pollutants that results from the friction between tires and the road, industrial activities and brick kilns. The concentration of $\mathrm{Zn}$ varied between $13: 133 \mathrm{mg} / \mathrm{kg}$ while the highest value of $\mathrm{Zn}$ was found in el Darb el Ahmr as a result of the traffic on the highway (Salah Salem road) and the industrial area. The toxic level is 100: $400 \mathrm{mg} / \mathrm{kg}$.

\subsection{Major elements}

The detected major elements are $\mathrm{Br}, \mathrm{Sr}, \mathrm{Mn}, \mathrm{Mg}$, $\mathrm{Fe}, \mathrm{Al}, \mathrm{Na}, \mathrm{Cl}, \mathrm{K}$ and $\mathrm{Ca}$. Figure 2 shows the major elements in the tree leaves at different sampling sites: Bromine (Br) concentrations are higher in Cairo than Menoufia. The high concentrations of $\mathrm{Br}$ are the result of the heavy traffic, motor vehicle exhaust fumes and the industrial areas. It is clear from the results that the high concentrations in Cairo viz. El Haram near the ring road and Tahrir areas are because of the traffic and the exhaust of the vehicles. The high concentration in Shubra El Kheima power station is the result of the power station exhausts. The high concentration in AlAmeriyya and Mustrod is the result of the industrial activities at this site. In Menoufia, the highest concentration was found in Sirs el Layyan also due to industrial activities in this area.

The concentration of Iron ( $\mathrm{Fe}$ ) is the highest in Menoufia near the train station of Al-Shuhadaa and the bus station of Ashmoun because of the wind-blown dust and brake dust from trains and buses.

The main source of the Strontium (Sr) is the road dust. The highest concentrations are detected in Ramsis, Tahrir and El Sayyeda Zainab locations. Tahrir and Ramsis are urban areas in Cairo.

The main sources of Calcium (Ca) are stack emissions from coal-fired power plants and boilers, 
and probably also emissions from waste incinerators [21].

The main sources of chlorine $(\mathrm{Cl})$ are the energy industry based on fossil fuels, coal, oil, natural gas, the production of brick, tile, enamel frit, ceramics, and glass; the manufacture of aluminum and steel; and the production of hydrofluoric acid, phosphate chemicals and fertilizers [20]. The level of $\mathrm{Cl}$ is higher in Cairo than in Menoufia Governorate; the highest concentration level is at El Darb El Ahmar then Shubra El Kheima power station.

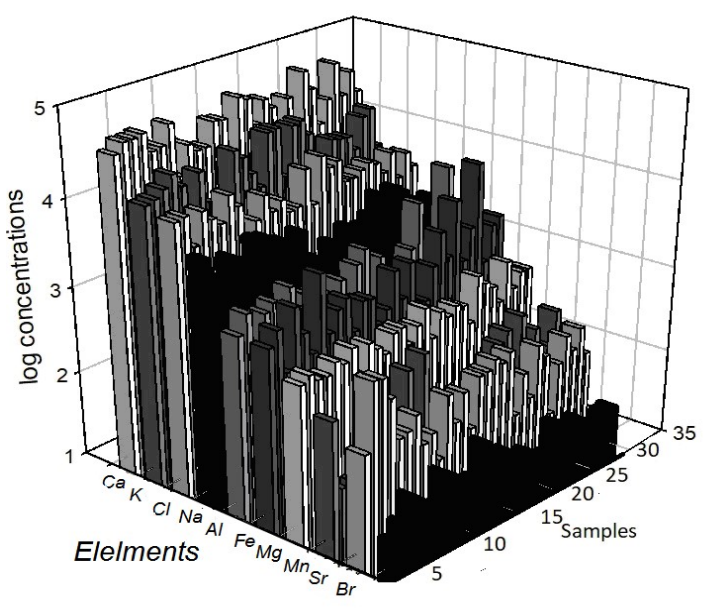

Figure 2. Log concentrations of Major elements in sampling sites

Potassium is an element required in relatively large proportions by a growing plant.

High Aluminum (Al) concentrations may be a result of Aluminum and steel industrial activities so there is a high concentration level at Al Shuhadaa and Sadat city industrial area in Menoufia Governorate. The waste water irrigation may lead to high concentration levels of $\mathrm{Al}$.

Crustal material from pavement abrasion is often rich in minerals containing Aluminum (Al), Potassium (K), Sodium (Na), and Calcium (Ca) [3].

Magnesium is very abundant in nature. So, high concentrations of $\mathrm{Mg}$ may come from soil uptake or wind-blown dust.

Manganese is essential to iron and steel production. At present, steel production accounts for $85 \%$ to $90 \%$ of the total demand. Manganese is the key component of low-cost stainless steel formulations and certain widely used Aluminum alloys.

\subsection{Trace elements}

The trace elements in the measured samples are $\mathrm{Rb}$, I, La, Sc, Th, Sm, Hf, Tb, U, Ta, Cs and Au. Figure (3) represent the variation of $\log$ (concentrations +1 ) of trace elements at the sampling site.

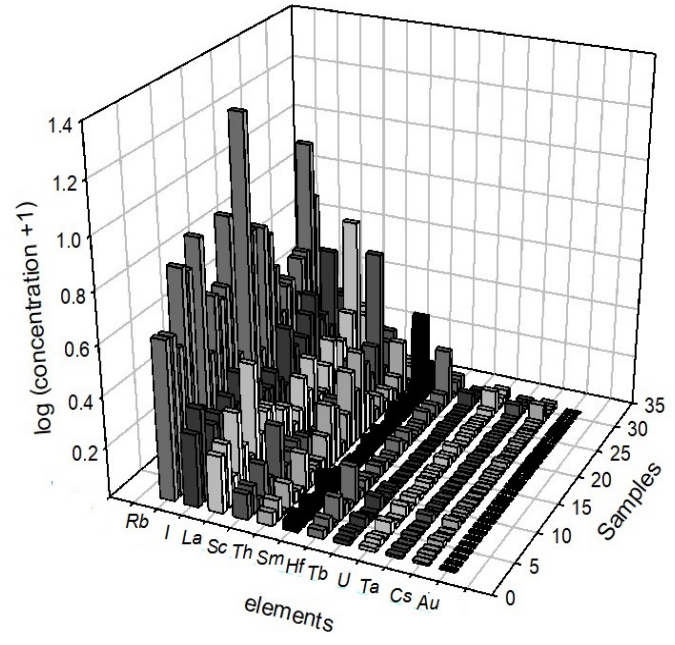

Figure 3. Log (concentration +1 ) of trace elements in sample sites

The main sources of Rare earth elements like La, $\mathrm{Sm}$ and $\mathrm{Tb}$ are wind-blown soil, motorized vehicles, industrial activities, stoves, incinerators, aerosol sprays, fumes from paint, and varnish[6]. It is clear that the Rare earth elements have symmetrical geochemical properties in the sampling sites; the highest concentration was measured in Al Shuhadaa followed by Shubra El Kheima power station. The highest concentration levels are related to fossil fuel burning and in Sadat city it is the result of the friction in gears and burning of oils used in the industries.

Uranium and thorium are naturally occurring elements and may be a result of wind-blown soil and may result from mixed sources like fertilizers [14].

Tantalum comes from the metallurgic activities. Due to the friction between trains and the railway, the highest concentration of $\mathrm{Ta}$ was measured in $\mathrm{Al}$ Shuhadaa.

Rubidium is related to paint, glass industries and wind-blown dust. So, it is reasonable that the highest concentration level was recorded in $\mathrm{Al}$ Ameriyya industrial zone the in Shubra El Kheima near Cystal Asfour glass factory.

Hafnium is related to ceramics industry, Brick industries and wind-blown dust may increase its amount. It is reasonable to have the highest concentration of $\mathrm{Hf}$ in Sadat city sample because of the ceramics factories in this area. The same applies to Cesium, which is used in many industrial activities.

\subsection{Comparing results with literature}

Figure 4 shows a tentative comparison of the mean concentration of each element measured in the present work against those in reference plant by Markert [22], [23] and the toxic levels [24], the reference values. 


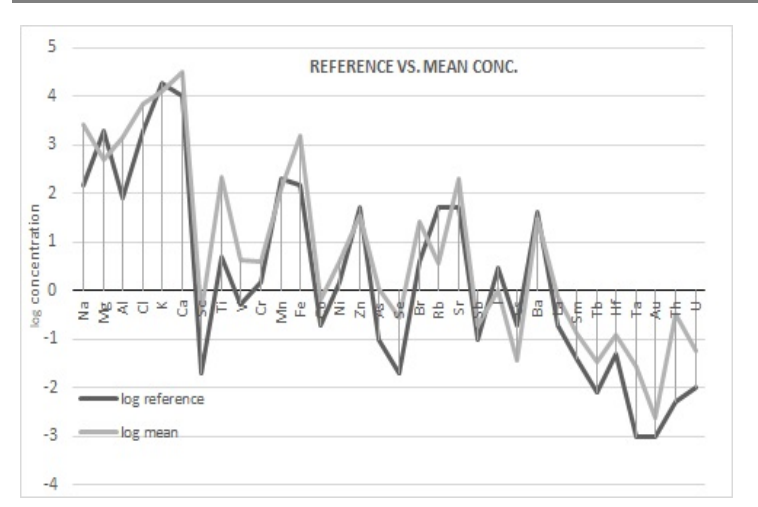

Figure 4. Log of Mean concentrations Vs. $\log$ of Reference plant concentrations

The mean concentrations in most of the measured elements are at least 3 times higher than the concentration in reference plant, viz. Ta, $\mathrm{Hf}, \mathrm{Tb}, \mathrm{Sm}$, $\mathrm{La}, \mathrm{Sr}, \mathrm{Ni}, \mathrm{Co}, \mathrm{Cr}, \mathrm{Ca}$ and $\mathrm{Cl}$.

However, the concentrations of $\mathrm{U}, \mathrm{Br}, \mathrm{Na}, \mathrm{Se}, \mathrm{As}$, $\mathrm{Fe}, \mathrm{V}, \mathrm{Sc}$ and $\mathrm{Al}$ are higher than those in reference plant by more than 5 to 10 times. The concentrations of $\mathrm{Th}$ and $\mathrm{Ti}$ are higher more than 20 times.

The concentrations of $\mathrm{Ba}, \mathrm{Cs}, \mathrm{I}, \mathrm{Rb}, \mathrm{Zn}, \mathrm{Mn}, \mathrm{K}$ and $\mathrm{Mg}$ are lower than the reference plant concentration.

\section{CONCLUSION}

However mosses and lichens showed the best biomonitoring capacity, tree leaves in our study represented a very good capability to monitor air pollution. The excess of concentrations of elements was related to the source of pollution around the areas under investigations.

The concentrations of $\mathrm{U}, \mathrm{Br}, \mathrm{Na}, \mathrm{Se}, \mathrm{As}, \mathrm{Fe}, \mathrm{V}, \mathrm{Sc}$ and $\mathrm{Al}$ in the measured samples are about 10 times higher than those in reference plant. However, the concentrations of $\mathrm{Th}$ and $\mathrm{Ti}$ are more than 20 times higher.

The concentrations of $\mathrm{Ba}, \mathrm{Cs}, \mathrm{I}, \mathrm{Rb}, \mathrm{Zn}, \mathrm{Mn}, \mathrm{K}$ and $\mathrm{Mg}$ measured values are lower than those in reference plant.

Ti shows high concentration in almost all sampling sites than recommended value (50 ppm). Elements like $\mathrm{Cr}$ and $\mathrm{V}$ show high concentrations in $\mathrm{Al}$ shuhadaa in Menoufia governorate then in Shubra el kheima power station site in Cairo governorate and 3 other sampling sites. Nickel concentration is higher than the recommended level (10 ppm) in shubra el kheima power station then in $\mathrm{Al}$ shuhadaa sampling site. $\mathrm{Mn}$ concentration is higher than that of reference concentration only in Nazlet el batran sampling site. Zn concentration is relatively high only in El Darb el Ahmar sampling site. There are no increase of toxic levels of $\mathrm{As}, \mathrm{Se}, \mathrm{Sb}$ and $\mathrm{Ba}$.

The toxic level of some elements is relatively higher than the published limits [24] in the areas of AlShuhadaa in Menoufia and Shubra El Kheima power station in Cairo.

Traffic and pollutants derived from friction with road are higher in Cairo than in Menoufia; this is revealed by the elemental concentrations of $\mathrm{Zn}, \mathrm{Sr}, \mathrm{Sb}$, $\mathrm{As}, \mathrm{Br}$ and $\mathrm{Tb}$.
High concentrations of $\mathrm{Cr}, \mathrm{Ba}, \mathrm{As}, \mathrm{Sb}, \mathrm{Cr}, \mathrm{Ni}, \mathrm{V}$ and Se were detected near the fossil fuel burning sites in $\mathrm{Al}$ Shuhadaa in Menoufia and Subra El Kheima electrical power station in Cairo.

The wind-blown dust is higher in Menoufia than in Cairo. This leads to high concentrations of $\mathrm{Co}, \mathrm{Fe}, \mathrm{Cr}$, $\mathrm{La}, \mathrm{Sm}, \mathrm{Ni}, \mathrm{Sc}$ and Ti.

\section{REFERENCES}

1. P. L. Kinney, "Climate change, air quality, and human health," Am. J. Prev. Med., vol. 35, no. 5, pp. $459-467$, Nov. 2008.

DOI: 10.1016/j.amepre.2008.08.025

PMid: 18929972

2. M. Brauer et al., "Exposure assessment for estimation of the global burden of disease attributable to outdoor air pollution," Environ. Sci. Technol., vol. 46, no. 2, pp. $652-660$, Jan. 2012.

DOI: $10.1021 /$ es2025752

PMid: 22148428 PMCid: PMC4043337

3. K. H. Kim, E. Kabir, S. Kabir, "A review on the human health impact of airborne particulate matter," Environ. Int., vol. 74, pp. 136 - 143, Jan. 2015

DOI: 10.1016/j.envint.2014.10.005 PMid: 25454230

4. A. Yalaltdinova, J. Kim, N. Baranovskaya, L. Rikhvanov, "Populus nigra L. as a bioindicator of atmospheric trace element pollution and potential toxic impacts on human and ecosystem," Ecol. Indic., vol. 95, pp. $974-983$, Dec. 2018. DOI: 10.1016/j.ecolind.2017.06.021

5. S. V. Gorelova, M. V. Frontasyeva, "The Use of Higher Plants in Biomonitoring and Environmental Bioremediation," in Phytoremediation, vol. 5, A. A. Ansari, S. S. Gill, R. Gill, G. R. Lanza, L. Newman, Eds., New York (NY), USA: Springer Int. Publ., 2017, ch. 5 , sec. 5.3 , pp. $103-156$. Retrieved from:

http://93.174.95.29/ ads/4B05012D1ADCCBC5C812A 088B059F8FE

Retrieved on: Apr. 15, 2019

6. A. A. Shaltout, M. I. Khoder, A. A. El-Abssawy, S. K. Hassan, D. L. Borges, "Determination of rare earth elements in dust deposited on tree leaves from Greater Cairo using inductively coupled plasma mass spectrometry," Environ. Pollut., vol. 178, pp. 197 - 201, Jul. 2013.

DOI: 10.1016/j.envpol.2013.03.044

PMid: 23583939

7. P. H. Freer-Smith, A. A. El-Khatib, G. Taylor, "Capture of Particulate Pollution by Trees: A Comparison of Species Typical of Semi-Arid Areas (Ficus Nitida and Eucalyptus Globulus) with European and North American Species," Water, Air, Soil Pollut., vol. 155, no. 1 - 4, pp. $173-187$, Jun. 2004. DOI: 10.1023/B:WATE.0000026521.99552.fd

8. A. A. El-Khatib, F. A. Faheed, M. M. Azooz, "Physiological response of Eucalyptus rostrata to heavy metal air pollution," El-Minia Sci. Bull., vol. 15, no. 2, pp. $429-451,2004$.

Retrieved from:

https://www.academia.edu/27489910/Physiological r esponse of Eucalyptus rostorata to heavy metal ai r pollution

Retrieved on: Apr. 5, 2019

9. M. V. Frontasyeva, "NAA for Life Sciences at Frank Laboratory of Neutron Physics, Joint Institute for Nuclear Research in Dubna," Ecol. Chem. Eng. S, vol. 18, no. 3, pp. $281-304,2011$. 
Retrieved from:

http://tchie.uni.opole.pl/freeECE/S_18 3/Frontasyeva 18(S3).pdf

Retrieved on: Apr. 5, 2019

10. M. Tomašević, M. Aničić, Lj. Jovanović, A. Perić-Grujić, M. Ristić, "Deciduous tree leaves in trace elements biomonitoring: A contribution to methodology," Ecol. Indic., vol. 11, no. 6, pp. 1689 - 1695, Nov. 2011.

DOI: 10.1016/j.ecolind.2011.04.017

11. W. M. Badawy et al., "Instrumental neutron activation analysis of soil and sediment samples from Siwa Oasis, Egypt," Phys. Part. Nucl. Lett., vol. 12, no. 4, pp. 637 644, Jul. 2015.

DOI: $10.1134 / \mathrm{S} 154747711504007 \mathrm{X}$

12. M. V. Frontasyeva, "Neutron activation analysis in the life sciences," Phys. Part. Nucl., vol. 42, no. 2, pp. 332 378, Mar. 2011 DOI: 10.1134/S1063779611020043

13. M. V. Frontasyeva, S.S. Pavlov, Analytical investigations at the ibr-2 reactor in Dubna, Rep. JINR-E--14-2000-177，Jt. Inst. Nucl. Res，Dubna, Russia, 2000.

Retrieved from:

http://citeseerx.ist.psu.edu/viewdoc/download?doi=10. 1.1.475.614\&rep=rep1\&type $=$ pdf Retrieved on: Nov. 3, 2019

14. A. I. Madadzada et al., "Assessment of atmospheric deposition of major and trace elements using neutron activation analysis and GIS technology: Baku Azerbaijan," Microchem. J., vol. 147, pp. 605 - 614, Jun. 2019.

DOI: 10.1016/j.microc.2019.03.061

15. A. Kabata-Pendias, H. Pendias, Trace Elements in Soils and Plants, 3rd ed., Boca Raton (FL), USA: CRC Press, 2001.

Retrieved from:

http://base.dnsgb.com.ua/files/book/Agriculture/Soil/ Trace-Elements-in-Soils-and-Plants.pdf Retrieved on: Jun. 14, 2019

16. M. Almeida-Silva, N. Canha, M. C. Freitas, H. M. Dung, I. Dionísio, "Air pollution at an urban traffic tunnel in Lisbon, Portugal: an INAA study," Appl. Radiat. Isot., vol. 69, no. 11, pp. 1586 - 1591, Nov. 2011.

DOI: 10.1016/j.apradiso.2011.01.014 PMid: 21288730

17. L. Qi et al., "Source identification of trace elements in the atmosphere during the second Asian Youth Games in Nanjing, China: Influence of control measures on air quality," vol. 7, no. 3, pp. 547 - 556, May 2016. DOI: 10.1016/j.apr.2016.01.003

18. Natural and Anthropogenic Sources of Trace Elements in the Environment, USGS, Reston (VA), USA.

Retrieved from:

http://www.cprm.gov.br/publique/media/gestao territ orial/geologia medica/natural anthropogenic sources .pdf

Retrieved on: Apr. 18, 2019

19. S. Zhou et al., "Trace metals in atmospheric fine particles in one industrial urban city: Spatial variations, sources, and health implications," J. Environ. Sci., vol. 26, no. 1, pp. 205 - 213, Jan. 2014

DOI: $10.1016 /$ s1001-0742(13)60399-x PMid: 24649708

20. S. Wilbur et al., "Potential for human exposure," in Toxicological Profile for Chromium, Atlanta (GA), USA: Agency for Toxic Subst. Dis. Regist., 2012, ch. 6 , pp. $363-399$.

Retrieved from:

https://www.atsdr.cdc.gov/toxprofiles/tp7.pdf Retrieved on: Sep. 12, 2019

21. S. Hoornaert, H. van Malderen, R. van Grieken, "Gypsum and Other Calcium-Rich Aerosol Particles above the North Sea," Environ. Sci. Technol., vol. 30, no. 5, pp. 1515 - 1520, Apr. 1996. DOI: 10.1021/es9504350

22. B. Markert, "Establishing of 'Reference Plant' for inorganic characterization of different plant species by chemical fingerprinting," Water, Air, Soil Pollut., vol. 64, no. 3-4, pp. 533 - 538, Sep. 1992. DOI: $10.1007 /$ BFoO 483363

23. B. Markert, "Instrumental multi-element analysis in plant materials: A modern method in environmental chemistry and tropical systems research," Environ. Geochem. Trop., pp. 75 - 95, Apr. 2006. DOI: $10.1007 /$ BFbo010907

24. A. Kabata-Pendias, H. Pendias, Trace Elements in Soils and Plants, 2nd ed., Boca Raton (FL), USA: CRC Press, 1992.

Retrieved from:

https://www.scirp.org/(S(351jmbntvnsjt1aadkposzje))/ reference/ReferencesPapers.aspx?ReferenceID $=160992$ 2 Retrieved on: Apr. 30, 2019 